\title{
A Contrapuntal Reading of Joseph Conrad's Lord Jim in the Light of Edward Said's Culture and Imperialism
}

\author{
Md. Nawsher Oan \\ Dept. of English, Hajee Mohammad Danesh Science and Technology University \\ Dinajpur, Bangladesh
}

A.S.M. Mahbubur Rahman (Corresponding author)

Dept. of English, Hajee Mohammad Danesh Science and Technology University

Dinajpur, Bangladesh

Md. Faisal Haque

Dept. of English, Hajee Mohammad Danesh Science and Technology University

Dinajpur, Bangladesh

Md. Lutful Arafat

Dept. of English, Hajee Mohammad Danesh Science and Technology University

Dinajpur, Bangladesh

\author{
Sohrab Hossain \\ Dept. of English, Bandarban University \\ Bandarban, Bangladesh
}

Received: June 3, 2021 Accepted: June 28, 2021 Published: June 30, 2021

doi:10.5296/ijele.v9i2.18822 URL: https://doi.org/10.5296/ijele.v9i2.18822

\begin{abstract}
This article targets to converge in analyzing the novel Lord Jim and Said's Culture and Imperialism to illustrate the critical development of the term 'contrapuntal reading' that demonstrates spatial rather than temporal relationship between them. This study deeply
\end{abstract}


endeavors to present the relation between the colonized and colonizer as it is marked in Said's Culture and Imperialism that demonstrates Conrad's Lord Jim while it exposes the relationship of Jim and all other characters and the experiences of Jim that he gathers in his journey in the novel. In addition, this study scrutinizes the different aspects related with the term 'contrapuntal reading'-colonialism, modernism and imperialism. However, qualitative approach has been applied to analyze the novel Lord Jim. As a consequence, this effort will pave the way to interpret the novel Lord Jim with an in-depth analysis that will lead the researchers to investigate other texts under the light of the term 'contrapuntal reading'. More specifically this research paper investigates the inner incidents that took place in the novel Lord Jim in the light of Said's Culture and Imperialism to establish various relationships as a contrapuntal reading study.

Keywords: Contrapuntal reading, imperialism, colonialism, modernism, historical events, novels

\section{Introduction}

According to Said, 'Contrapuntal reading' is reading a text with an understanding of what is involved when an author shows (78). For instance, in his reading of Mansfield Park Said shows how the contrapuntal reveals the significance of a colonial sugar plantation in the process of maintaining a particular style, narrative and of social space in England. Moreover, like all literary texts, Culture and Imperialism and Lord Jim are not restricted by their formal historic beginnings and endings. It is bounded by the concept of modernity of the western civilization. In Culture and Imperialism, we see that it is the relation between the colonized and the colonizer and also the relationship between the master and slave in India, Pakistan, Saudi Arabia like the western post-colonial territories in the imperialist society, France's colonialism in Algeria is for example. Actually, the contrapuntal relates to or is characteristic of the counterpoint, or having two or more indented but harmonically related melodic parts sounding together which implies the concurrency of two antiphonal elements necessary for each other's development like the sounding of a musical instrument. In Said's book, we see that he connects this by looking at the different experiences and the ways by which they reveal a set of what he calls "intertwined or overlapping histories" (19). He formulates an alternative both to a politics of blame and to the even more destructive politics of confrontation and animosity. Again, the contrapuntal refers to the oppositional, often not immediately visible or easily perceptible, in a text or a book. It is the inner contradiction between the two opposite forces which shows some obvious result. It is actually the psychological and metaphysical presupposition which we can guess and assume. It is very difficult to portray. Our aim is to relate this in the secular world with the temporal in the text of Lord Jim by Joseph Conrad.

\section{Literature Review}

Contrapuntal reading is viewed in innumerable proportions to rediscover the relationship as the 
text conveys the meaning underlying with the author's presentation of the text. As we observe, in Orientalism, Edward Said defines the relationship between the Occident and the Orient as one of power and domination, positing Orientalism as an exclusively male phenomenon, and the Oriental woman a projection of European male fantasy. Edward Said defines the relationship between the Occident and the Orient as one of power and domination ( Mortimer, Mildred 2005). In Culture and Imperialism Edward Said analyses a plethora of literary works, particularly the ones written by colonial authors who used the colonised countries as settings for their plots (Ouahida, Mrs Aissaoui, 2018). In another perspective, the contradictions defining Said's personal history suggest a more complicated and compelling model of the politics and epistemology of cultural difference (Armstrong, Paul, 2018). By analyzing Edward Said's 'contrapuntal' perspective, a relational urban geography is proposed which is more sensitive to the ontological limitations of theory, and which takes a provisional approach to conceptualising and writing about cities (O'Callaghan C, 2012). As Edward Said's contrapuntal reading, borrowed from Western classical music, weaves his arguments and is central to his unique articulation of the concepts of contrapuntality and fugue (Chowdhry, Geeta, 2007). But Edward Said's Culture and Imperialism offers as one strand of its multifaceted discussion, methodological reflections on the reading and interpretation of the works of narrative fiction. More specifically, Said delineates and defends what he calls a contrapuntal reading or (analysis) of the text in questions (Wilson, George M,1994). So, Edward Said's notion of contrapuntal reading is tested by two novels representing the fifth year of Israeli occupation of the West Bank (1972) _ "Wild Thorns," written by (Palestinian) Sahar Khalifeh, and "The Smile of the Lamb," written by (Israeli) David Grossman in the Israeli/Palestinian context (Metres, Philip, 2010). Now as we see, contrapuntal reading (a type of reading developed within postcolonial studies) is engaging the Gospel of Matthew and the current global and local contexts of migration that demonstrates the mode and the significance of such readings and ways in which the approach could be brought to bear in a range of contemporary contexts and in relation to any number of current global and local issues (Wainwright, Elaine M, 2014). Even in poetry, the writings of Shelley and Marechera do raise important questions about society and the state and continue to address serious political issues that grow and develop with each new reading, it is continually changing, and for this reason it is essentially moving as depicted in contrapuntal reading (Mushakavanhu, Tinashe, 2017). Again, Edward Said's contrapuntal reading strategy helps to shed light on the dark spots of the novel, give voice to the unheard characters of the original story, and uncover new meanings and new aspects of the story (Pourgiv, Farideh,2017). Most of the researcher's emphases on contrapuntal reading in dissimilar aspects to ascertain their objectives but in this research article we have strived to assess a novel in the light of Edward Said's own creation Culture and Imperialism to investigate the novel Lord Jim as a contrapuntal study.

\section{Spatial and Temporal Relationship in Culture and Imperialism}

Past and present conflict is very important in Said's book. The historical events that inform a book do not compel a man only to write only about the past generation, event or the experiences in the past but he has also a chance to write about the present and future. This is 
the co-existence of the past and the present which suggests a contrapuntal relationship with a feeling in Culture and Imperialism that "the whole of the literature of Europe from Homer to the current age in the whole of the literature of his own country which has a simultaneous existence and composes a simultaneous order" (2). Historical sense is the sense of the timeless and of the temporal together, what makes a writer traditional. By the term historical, we seem to understand that what is all about the past and to arrange their organization systematically into a table with metaphysical binary. Eliot's synthesis of past, present and future is idealistic and in important ways a function of his own peculiar history. The central idea is how we formulate or represent the past shapes our understanding and views of the present. Said quotes from Eliot that "Eliot's idea about the complexity of the relationship between past and present are particularly suggestive in the debate over the meaning of 'imperialism' as a word or an idea today so controversial, so fraught with all sorts of questions, doubts, polemics, and ideological premises as merely to resist use altogether" (3).

\subsection{Imperialism as a Highly Concerned Term}

Imperialism is one of the most important and interested concerns in Said's book. He always wants to argue against the imperialism and he would like to connect this with his disfavourable argument against imperialism. He shows how the colonized people could be free from the force of imperialism. Imperialism is a kind of invasion or conquest using military forces. The imperialist shows that their aim is to civilize the savages but their actual aim is something different from what they really mean. They think that the colonized people have no history but the European or the civilized have their own history. Africa is a contrast with history and outside history. It is very difficult to define the existence of the savages. The civilized does not think the colonized people as human beings. From an ontological perspective, we can say that the subject's ability to reproduce the very concept of being as a possibility is denied to the colonized. The representation of the "other" as a human being appears to be an unimaginable possibility for the colonizer. According to Said "Imperialism means thinking about, settling on, controlling land that you do not posses, that is distant, that is lived on and owned by others" (5). It is actually good days for the people of superior and powerful classes who attack the inferior but the inferior suffers an untold misery. In the novel Heart of Darkness, we see the Europeans capture the land and culture of the Africans and it continues a lot of years. In this stage, we would like to expose the contrapuntality and colonial subjectivity of Conrad's Lord Jim and its relation with Said's Culture and Imperialism.

Actually, the aggression of the white people of the western world started a long time ago. And it continues till today but in a different shape. The Western metropolitan world and their counterparts are sharing a sense of high or classical colonial imperialism in the third world which come to a climax in what the historian describes as the age of empire. During the nineteenth century some countries such as Italy, Spain, Iraq, Constantinople are attacked by the unprecedented power of Britain and France and later by the other Western countries like United states. In this century we see that this is the climax and rise of the West. 
Said avers-

\begin{abstract}
"Neither imperialism nor colonialism is a simple act of accumulation and acquisition. Both are supported and perhaps even impelled by impressive ideological formations that include nations. Imperial culture is plentiful with the words and concepts as 'inferior' of 'subject races', 'subordinate peoples', dependency', 'expansion' and authority (8)."
\end{abstract}

The predominance of the British and French empires obscures the quite significant new expansion of Spain, Portugal, Holland, Belgium, Germany, Italy and in a different way Russia and the United States. Overseas expansion and domination in the world we see very repeatedly mentioned in Said's book. It is actually the hegemony of the superpower. The aggressions do not take place only in Africa but also in different Asian countries that are attacked and invaded sometimes by the different superpowers illegally, a fact which is repeatedly mentioned. Said's argument about the Gulf war and Iraq's invasion against Kuwait concerning oil is very obvious (21). He does not support this.

According to Said,

"a new and appalling tribalism is fracturing societies, separating people, promoting greed, bloody conflict, and uninteresting assertions of minor ethnic or group particularity. Little time is spent not so much in learning about other cultures" (21).

One significant contemporary debate about the residue of imperialism is the matter of how the 'natives' are represented in the western media, an event that illustrates the persistence of such independence and overlapping. By the western media, the oppressed are represented very nakedly and sometimes as terrorists but they are not terrorists, they actually would like to save themselves from the grab of terrorism but their hues and cries do not reach in the ear of the superpowers. Superior European countries are dominating and ruling different countries and sometimes we see American invasion in the weaker countries and the weaker countries are continuing their struggle against the terrorism of the superpowers.

\title{
4. Findings and Discussion
}

To relate this to contrapuntality, we would like to give a brief story of Lord Jim. Jim is an English merchant who is hired as a first mate on the Panta. It is a very old cargo bearing eight hundred Islamic pilgrims. On a calm night, the ship faced the danger of sinking. A forward partition appears ready to give way. If it does the ship will go down in an instant. The captain 
and the three officers beside Jim immediately engage themselves having a lifeboat free and jump into the water. Jim stands watching, but at the end point jumps into the water with lifeboat and with the other. Then they are rescued and make landfall, only to learn that the Panta did not sink. All the passengers are safe and everyone in the Eastern seas knows of the affair. The shame of it follows Jim for years forcing him out of job after job and pushing him to the age of becoming an abandoned. Finally, through the good offices of Marlow Jim is given a trading position in Patusan an isolated and remote interior village. There he appears to convert himself, performing an exploitation of heroism, protecting the local inhabitants against the local tyrant, finding in love of his life and becoming venerated as "Tuan Jim" Lord Jim. All seems well but the Patusan is invaded by gentleman Brown, a desperate and ferocious pirate. Jim misjudges Brown and the result is the death of many of the villagers under his care including Dain Waris. Jim's friend and the son of the chief who had helped and protected Jim when he first came to Patusan. In compensation, Jim presents himself to the chief for execution and is killed.

We see Brown along with his mates goes to Patusan in search for food and for their "requirement". Here requirement means to plunder the things possessed by the people of Patusan. When they go to Patusan they immediately are caught by the people of Jim. Then they have had some sufferings and Jim confronts Brown. In this session they have a brief conversation. In one point, Brown agrees to leave Patusan. Brown then disdains Dain Waris along with other members of Waris tribe. Here lies the colonialistic zeal of Conrad. So, Patusan is invaded by the white people for fulfilling their colonial intension. Brown is absolutely well-known because of his colonial exploitation and however, Jim associated to the pilgrims his "missed chance" and now relates to the Patusan folks as his "magnificent chance", Brown's unfair and unusual ways reduce Jim's own selfish but risk-free reasons. In fact, the novel pays concentration more than criticize the colonization of foreign land and people- it endows both the land and people with active power, an aspect that is swiftly snatched away from them in the act of colonialism. For example, the novel not only depicts how the Patusan folks need Jim but how Jim needs them as well.

Jim's moral failure is very transparent in this story when we observe his attitude while jumping into the water. This is his mistake but at all times and in all jobs, mistake is not permissible. Mistakes sometimes bring bad luck for the human beings and sometimes challenge the fate of humanity. So, everyone should be careful in his doing when he becomes a responsible person in the society or for responsible works. This happens to the life of Jim. He wants to be a hero but his moral failure has a bad judgment for moral criticism.

According to Tanner,

"Lord Jim is the study of a man whose will is valiant and his behavior is craven, who is bravely active in his intension and disastrously passive in his deeds, whose ideal aspirations are courageous and whose real conduct in a crisis is ignoble. In him the best and the basest of human motives are ominously 
interwoven" (7).

This is actually the contrapuntal thing by which we can get the two opposite meanings, forces and how these things are textured or interwoven by the novelist Conrad. By the act of imagination, he thinks himself as a hero but in the reality, he is a coward who does not take initiative in the bad times of his mates or in the bad circumstances when he faces the reality. Sometimes, he upholds the status and sometimes betrayed with his existence, which gives sometimes life's dignity and sometimes fails to uphold the actuality. Tanner further says "He is a martyr and a betrayer, a Christ who acts like Judas, a Judas who dies like Christ" (7). From the reading of the book, we see Jim as a very simple man but his simplicity sometimes raises some problems which are very multifarious and philosophical. We can see this when he escapes himself from jumping into the water to save the life but finally, he does this. He actually does not face any real danger before. Hero in this novel is shown as suffering from a lack of motivation in Jim's drifting life as a water-clerk. In the end, Marlow attributes the ship's capability to drift to tough old iron, and his proposal momentarily confounds the secularity of the Western thought So, studying Conrad is very much critical. We see, there are two sides of a thing in Conrad's view. It is the man who stimulated Conrad to one of his majors enquires into the nature and sometimes the amazing range of his capabilities and the endless inner and outer threats which he is condemned to confront. The hero then summarizes the values and ideals of the tribe or he may epitomize various anti social dreams and revolts. He is usually celebrated and revered but he may also be challenged and ridiculed by the mock heroics, satire and irony. It brings out the inner weakness as well as reveals the essential inaptness for the external concrete world.

Conrad's narrative technique is also contrapuntal. He goes forward and backward just like Said in his book Culture and Imperialism. Said repeatedly says the same thing, sometime goes forward and come backs to backward and this is a natural thing to them. Conrad is moving towards a world of epistemological skepticism in which the whole truth can never be known. As Marlow puts it, we now move in a world where fullness of utterance has given way to tentative stammering and always the last word is not said. To get the full significance of Jim, Conrad moves cautiously and meditatively around his accumulated substantial listening to many voices soliciting different opinions; he comparing many unimportant experiences, juxtaposes segments of past and future so that time in this novel is no longer a linear track on which one thing follows another. Here in this novel, things are interwoven in the surface on which they are laid out in an uncontrollable array which is both confused and significant, random and meaningful.

According to Krishnan,

"Marlow's narrative alternately presupposes a hierarchy and an absolute Gulf that separates European from native consciousness in the novel. Even the least sympathetic or thoughtful Europeans, such as the German captain or the 
second engineer of the Patna, possess the capacity to evaluate and to judge" (328).

The description of pilgrims starts with "they steamed with earth by faith and after seeming to giving credit to their religious conviction. The description ends by describing them as "unconscious pilgrims of an exacting faith" (12). In this text we also see that religion and race are ridiculed in a harsh satirical tone here. Western space for the pilgrims were coming from North and South and from the outskirts of the East. "They were like the German skipper says "Cattle" and "human cargo" or body parts such as "a dark hand" or a throat bared and stretched as if offering itself to the knife for even their body parts suggested their vulnerability to the colonizers subjectivity. In the end Marlow attributes the ships' ability to float to tough old iron his suggestion temporarily confounds the secularity of the western thought. Their greed is also criticized behind colonial journey against the nature of the civilizing mission.

Before going on any further, we firstly consider how colonialism and modernism affects this novel. Colonialism is manifested in Lord Jim in the form of the pilgrim and more importantly in the island of Patusan and its people. Colonialism actually complicates this novel because of the denouncement of the enterprise exists side by side with its validation. In this novel we get some touches of modernism in connection with colonialism. Modernism in fact does not just mention upon colonialism- it approaches the latter in a full new mode. This text, Lord Jim issues philosophical statement with colonialism.

"That kind of thing" was only endurable and enduring when based on a firm conviction in the truth if ideas racially our own, in whose name are established the order, the morality of an ethical progress (212).

The binarism or Manicheanism that normally holds colonialism in place and even justifies it, collapses in the face of modernism because the aesthetics of modernism allow it to present not one universal way of looking at the colonized subjects or colonial journeys, but rather a multitude of ways.

The title of the novel has an importance. This is not Jim or something like that but it is "Lord Jim" and it has some inner significance which shows the life of the ordinary water clerk and chief mate and is considered as a virtual ruler of Patusan. Its political environment has a terrible effect which gives him a chance to become a hero. When Jim finally colonizes Patusan he establishes his status as 'Tuan Jim' and reinforces a colonial binarism.

In this novel, we get the impression that the colonists are not explorers or saviours and are considered as the greedy merchants and captures the resources of Patusan. Conrad satirizes this in a very sarcastic manner. In fact, it does more than denounce the colonization of the foreign land and people. They occupy the land and people with the active power and 
snatched away the important belongings of the inhabitants of Patusan. The novel actually illustrates the necessity of the Patusan to Jim and Jim's intermingled role in exploiting the people of Patusan through a detective story. The quest to recover meaning is central in the two text of Conrad's Heart of Darkness and Lord Jim co-existing with Marlow's inquiry for blank space and Jim's cherishes for a clean state.

The representation of interiority (in narrative) and progress (in history) is not easily loosened in the empirical oppression. It is a very common phenomenon and is continuing all times and in all the ages. Joseph Conrad is necessarily arguing against racism also which is a burning issue to him and very deeper in postcolonial studies. It is a common problem and obvious risk of difference and is thematized within the modern. So, we should create a certain thought against colonial rule and hegemonic oppression through models of economic development. In fine, it can be said that the era of high nineteenth century imperialism is over. France and Britain gave up their most splendid possessions after World War II and lesser powers also divested themselves on their far-flung dimensions.

\section{Conclusion}

Intertwined perspectives become the focal point of a contrapuntally analyzed piece of fiction. In this paper, like the other colonial texts the perspectives of the colonizers and colonized of the novel Lord Jim have been interpreted with contrapuntal analysis developed by Edward W. Said in his Culture and Imperialism. To interpret a text contrapuntally is to interpret its different perspectives simultaneously and to mark how it interacts with itself as well as with biographical or historical contexts. Jim's desire to be a hero remained unfulfilled in reality. His career at Panta proved him an invalid coward. Contrarily Jim at Patusan gradually began to be a hero. But eventually out of his misjudgment of the opposite, has to lose Doramin's son that brings his ultimate downfall. We can see contrapuntality in Jim's biographic context. Keeping similarity with Jim's biographic context, the hegemonic motives of the colonizers can be disposed with contrapuntal interpretation of the postcolonial perspectives. And this is particularly applicable in Joseph Conrad's novels like Lord Jim and Heart of Darkness.

\section{References}

Armstrong, P. B. (2018). 3. Being" Out of Place": Edward Said and the Contradictions of Cultural Differences. In Play and the Politics of Reading (pp. 42-60). Cornell University Press. https://doi.org/10.7591/9781501720659-004

Brudney, D. (1998). Lord Jim and moral judgment: literature and moral philosophy. The Journal of Aesthetics and Art Criticism, 56(3), 265-281.

Chowdhry, G. (2007). Edward Said and contrapuntal reading: Implications for critical interventions in international relations. Millennium, 36(1), 101-116. https://doi.org/10.1177/03058298070360010701 
Krishnan, S. (2004, July). Seeing the Animal: Colonial Space and Movement in Joseph Conrad's Lord Jim. In Novel: A Forum on Fiction (Vol. 37, No. 3, pp. 326-351). Duke University Press.

Metres, P. (2010). Vexing Resistance, Complicating Occupation: A Contrapuntal Reading of Sahar Khalifeh's" Wild Thorns" and David Grossman's" The Smile of the Lamb". College Literature, 81-109.

Mortimer, M. (2005). Edward Said and Assia Djebar: a contrapuntal reading. Research in African Literatures, 53-67.

Mushakavanhu, T. (2017). Anarchies of the Mind: A Contrapuntal Reading of the Poetry and Prose of Percy Bysshe Shelley and Dambudzo Marechera (Doctoral dissertation, University of Kent).

O'Callaghan, C. (2012). Contrapuntal urbanisms: towards a postcolonial relational geography. Environment and Planning A, 44(8), 1930-1950. https://doi.org/10.1068/a44615

O'Hara, D. (1984). Criticism Worldly and Otherw orldly: Edward W. Said and the Cult of Theory. Boundary, 2, 379-403.

Ouahida, Mrs Aissaoui. (2018). Edward Said Analysis of Literary Works in Culture and Imperialism. Diss. Ministry of Higher Education.

Pourgiv, F. (2017). A Contrapuntal Reading of Daniel Defoe's Robinson Crusoe. Journal of Humanistic and Social Studies, 8(2), 39-50.

Said, E. W. (1994). Culture and imperialism. London.

Tanner, Tony. (1963). Conrad: Lord Jim. London.

Wainwright, E. M. (2014). Crossing over; taking refuge: A contrapuntal reading. HTS Theological Studies, 70(1), 01-06. http://dx.doi.org/10.4102/HTS.V70I1.2720

Wilson, G. M. (1994). Edward Said on contrapuntal reading. Philosophy and Literature, 18(2), 265-273. https://doi.org/10.1353/phl.1994.0025

\section{Copyright Disclaimer}

Copyright for this article is retained by the author(s), with first publication rights granted to the journal.

This is an open-access article distributed under the terms and conditions of the Creative Commons Attribution license (http://creativecommons.org/licenses/by/4.0/). 